\title{
Business Start-Ups or Disguised Unemployment? Evidence on the Determinants of Self-Employment from Urban China
}

\author{
Xinxin Ma \\ Institute of Economic Research, Hitotsubashi University, Tokyo, Japan \\ Email:maxx@ier.hit-u.ac.jp
}

Received 11 July 2016; accepted 1 August 2016; published 4 August 2016

Copyright (C) 2016 by author and Scientific Research Publishing Inc.

This work is licensed under the Creative Commons Attribution International License (CC BY). http://creativecommons.org/licenses/by/4.0/

(c) (i)

\section{Abstract}

This study provides evidence on the determinants of self-employment for urban local registration residents in China. Using CHIP2007, the employment status is divided into four categories: selfemployed employers, own-account workers, employees, and the unemployed. Several major conclusions emerge. First, compared with the employee, holding other factors (e.g., human capital) constant, the wage premium associated with the self-employed employer is higher, while the wage premium associated with own-account workers is lower. Second, the influence of the wage premium on the self-employed employer is negatively significant, and the influence of the wage premium on the own-account workers is insignificant. These results reveal that compared with employees, being a self-employed or own-account worker is seemingly not a better choice for employment in urban China; being self-employed is similar to disguised unemployment. Third, considering the influence of all the factors: the wage level categories (wage levels in the public and private sectors), the entry period categories (the SOE reform period and the recent period), the age categories (aged 50 and over, and aged below 50), and the regional categories (the East, the Central, and the West regions), robust checks were conducted. In the own-account workers group, the business creation hypothesis is nearly rejected again; in fact, it is only supported for workers who entered the self-employment sector in the SOE reform period (entered early into the selfemployment sector group), and workers aged over 50.

\section{Keywords}

Self-Employment, Economic Transition, Business Creation, Disguised Unemployment, Urban China 


\section{Introduction}

The self-employed sector is a representative informal sector of the employment market as noted in previous studies ${ }^{1}$. Schumpeter described the sector as the "prime mover of economic growth" (Schumpeter, 1943). De Soto (1989) described the emergence of self-employed workers as "the foundation of development." Transition economists believe the rise of self-employment to be a sign of the growing importance of markets relative to the state (Hanley, 2000; Dimova \& Gang, 2007). Along with the economic transition in urban China, the number of self-employed workers ${ }^{2}$ increased from 150 thousands in 1978 to 21.36 million in 2000, before further increasing to 52.27 million in 2011 (NBS, 2012).

Why was there a large change in the size of the self-employed sector in urban China during the economic transition period? There are two primary possible explanations. The first is the great increase in the number of migrants along with economic development and the deregulation of the registration system after the 1980s. The second explanation is that along with the transition from a planned to a market economy, the government enforced ownership reform of State-Owned Enterprises (SOEs) from the 1980s onward. A section of employees with urban registration in the SOEs became laid-off workers and some of them re-employed in the informal sector (e.g., by becoming self-employed workers). In addition, a section of workers voluntarily left SOEs to become owners in the private sector. This paper discusses the determining factors for the self-employed workers in urban China.

There are two hypotheses about self-employment discussed in previous studies. One is the "disguised unemployment hypothesis," which is indicated in the dualism theory of Todarro (1969) and Harris and Todarro $(1970)^{3}$. Migrants to the informal sector can be explained by this hypothesis, as in the case of workers in SOEs who lost their jobs because of SOE reconstruction. Most laid-off workers were not re-employed by SOEs, so many entered the informal sector (e.g., to become self-employed workers) in order to make a living (Knight \& Song, 1999). Considering the above, self-employment may result from forced recourse to the informal sector, in which the individual's activities and wage slightly differ from what they would be if the individual were unemployed. It is thought that self-employed workers barely make a living from working, receiving lower wages and working longer hours than those in the formal sector. Conversely, self-employed workers may also be successful business owners who create new business opportunities and many innovative new products ("business creation hypothesis”). For example, along with ownership reform beginning in the 1980s, some workers left SOEs to become owners of private firms and started new businesses. A number of these new entrepreneurs (employers) were communist party members or cadres in the public sector in the past, and it has been pointed out that such social capital positively affects the premium that may be associated with self-employment (Wu, 2006) ${ }^{4}$.

As a result, a high percentage of self-employed workers may reflect an environment that encourages risktaking, business creation, and market development ("business creation hypothesis"), or it may be a result of the lack of jobs in the formal sector in which wages are set just above the market-clearing level ("disguised unemployment hypothesis").

Which hypothesis can explain self-employment in urban China? In this paper, we provide some evidence to answer this question ${ }^{5}$. In the previous empirical studies on this issue, although Earle and Sakova (2000), Hanley (2000), Dimova and Gang (2007) utilized microdata of Central and Eastern European economic transition countries to test these two hypotheses, there has not been an empirical study for China. One of the purposes of this

\footnotetext{
${ }^{1}$ For detailed surveys of empirical studies on self-employment, please see Yamada (1996), and Le (1999).

${ }^{2}$ There is no unified definition of self-employed workers in previous studies in China. Based on the survey data used in the paper and firm classification rules, we defined self-employed workers as those who work in a small firm with less than eight employees or who work in a firm made up entirely of the self-employed worker and unpaid family members.

${ }^{3}$ According to the dualism theory in development economics, in the prior period of economic development, there exist surplus labors in traditional sector (e.g., agriculture industry sector), when modern sector (e.g., manufacturing industry sector) offer wage closed or a little more than subsistence wage level, migration from the rural region to the urban region will occur until the economy pass the Lewis's turning point (Lewis, 1954). Todarro (1969), Harris and Todarro (1970) developed Lewis model and pointed out that migrants expect the high wage of modern sector in urban market, so when he doesn't find the job in the formal sector immediately, he always worked in the informal sector (such as self-employment sector) to wait (or do a job search) for the formal sector job. ILO (1972) indicated that working in the informal sector also can contribute economic development for developing countries.

${ }^{4}$ The phenomenon of communist party members and cadres leaving the public sector to become business owners in the private sector in the 1980s is called "Xia Hai” in Chinese.

${ }^{5}$ Reviewing empirical studies on the determinants of self-employment in China, Wu (2006), Yueh (2009a, 2009b), Zhang and Zhao (2015) pointed out that the factors of human capital, family background, liquidity constraints, party membership and social capital affect the choice to becoming a self-employed worker.
} 
paper is to resolve this dearth in empirical data.

This paper is structured as follows. Section 2 reviews the literature, and Section 3 describes estimate methods, including introduction to the data and models. Section 4 states descriptive statistics and estimated results, and Section 5 presents the main conclusions.

\section{Methodology}

\subsection{Models}

Firstly, to explicate the determinants of the self-employed in urban China, the employment status probability function is estimated using a multinomial logit model, which is represents in Equation (1). The explained variable takes on one value for four categories of employment status (self-employed employer, own-account worker, employee, and the unemployed). Here, referring Earle and Sakova (2000), Hanley (2000) and Dimova and Gang (2007), we defined own-account workers are those who work in small firms (or unit) which only him (herself) or no-paid family workers work in, self-employed employees are those who work in small firms with workers less than eight and they are the owners of these small firms. The reference category is the employee group.

$$
\operatorname{Pr}\left(Y_{i}=n\right)=\frac{\exp \left(a_{n}+\beta_{X n} X_{n i}\right)}{\sum_{m=1}^{r} \exp \left(a_{m}+\beta_{X m} X_{m i}\right)}
$$

In Equation (1), $i$ denotes workers, $m(m=1, \cdots, r)$ denotes employment status as the above. $\operatorname{Pr}\left(Y_{i}=n\right)$ indicates probability of one kind of employment status, $X$ are factors affecting the employment status probability, $\beta$ are the estimated coefficients, and $\alpha$ is a constant.

Then we used two kinds of methods to test the "disguised unemployment hypothesis" and "business creation hypothesis". The one is a comparison of average wage levels of self-employed employer group, own-account worker group and employee group (Hanley, 2000). For example, holding the other factors (such as human capitals) constant, if the average wage level of own-account worker group is lower greatly than employee group, it shows that own-account workers are nearly the disguised unemployed, and labor market is segmented. In order to gain these imputed wage, wage functions by different employment status groups are estimated. Here, Maddala (1983) model is used to deal with the sample selection bias problem, which has been shown in Equations (2.1)-(2.3).

Wage functions estimated by OLS (Ordinary Least Squares) model is expressed as Equation (2.1).

$$
\log \text { Wage }_{i}=b+\gamma_{E m p} \text { Emp }_{i}+\gamma_{H} H_{i}+u_{i}
$$

In Equation (2.1), $i$ denotes workers, and log Wage indicates the dependent variable (as the logarithm of wage rate). $E m p$ is an index indicating employment status (self-employed employer, own-account worker and employee), $H$ are factors affecting earnings. $\gamma_{E m p}$ and $\gamma_{H}$ are the estimated coefficients. Further, $\alpha$ is a constant and $u$ is the error term.

Considering the selection bias problem in Equation (2.1), the selection bias corrected wage function model is proposed (Maddala, 1983). Equation (2.2) expresses the probability of employment status using the probit regression model. For example, the probability to become a self-employed employer is expressed as $\operatorname{Pr}\left(Y_{i}^{*}=1\right)$, and the other probability (such as employee, own-account worker, the unemployed) is expressed as $\operatorname{Pr}\left(Y_{i}^{*} \neq 1\right)$. $X$ are factors identical to those expressed in Equation (2.1), the identification variabels ${ }^{6}$ are used for Equation (2.2) and Equation (2.3). Using the estimated results of the normal distribution function and the density function based on the probit regression model which is expressed by Equation (2.2), selectivity items $(\lambda=\phi(\beta X) / \Phi(\beta X))$ are calculated. The corrected wage functions expressed by Equation (2.3) can be estimated using these selectivity items.

$$
\begin{gathered}
Y_{m i}^{*}=a_{m}+\beta_{X m} X_{m i}+\varepsilon_{m i} \quad(i=1,2, \cdots, N) \\
Y^{*}=1 \text { if } \beta_{n} X_{n}-\beta_{m} X_{m}>\left(a_{m}-a_{n}\right)+\left(\varepsilon_{m}-\varepsilon_{n}\right) \quad(m \neq n) \\
\log \text { Wage }_{i}=b+\gamma_{E m p} E_{m}+\gamma_{X} H_{i}+\gamma_{\lambda} \lambda_{i}+u_{i}
\end{gathered}
$$

${ }^{6}$ Child, household income, family background, social capitals are used as identification variables in the study. 
The other test is the estimation of the effects of earning premiums on the probability of employment status (Earle \& Sakova, 2000). We utilize a multinomial logit model shown in Equation (3). In Equation (3), wage premiums (WP) are added as new variables, the other variables are similar with Equation (1). It is thought that higher the wage premium, higher the probability to choice the employment status. For example, when the estimated results of wage premium ("Wer/Wee") is positive significantly on the probability to become a selfemployed employer, it is shown that the self-employment is a new business to gain more income and create more values (such as create new jobs for others, and new goods), so the "business creation hypothesis" is supported. While, when the estimated results of wage premium ("Wer/Wee") is negative significantly (or insignificantly) on the probability of self-employed employer, it is shown that although becoming a self-employed employer can't gain more, he (she) has to choice to become a self-employed employer, it indicates that the entry to the informal sector may be an involuntary behavior, and "disguised unemployment hypothesis" is supported.

$$
E\left(\operatorname{Pr}\left(Y_{i}^{*}=1\right)\right)=\frac{\exp \left(a_{n}+\beta_{W P} W P_{n i}+\beta_{X n} X_{n i}\right)}{\sum_{m=1}^{r} \exp \left(a_{m}+\beta_{W P} W P_{m i}+\beta_{m} X_{m i}\right)}
$$

\subsection{Data}

The 2007 Chinese Household Income Project Surveys data (CHIP2007) are used for the analysis. The survey was conducted by NBS (National Bureau of Statistics) and Beijing Normal University in December 2008 including respective information about employment status and wages of the urban registration residents. The survey selected the represented districts in China, including the East region (Liaoning, Jiangsu, Guangdong), the West region (Sichuan, Yunnan, and Gansu), the Central region (Beijing, Shanxi, Henan, Hubei, Anhui). The sampling method is stratified random sampling method based on the national samples of the NBS.

From the above, the dependent variable is an employment status category variable. The independent variables are as follows (Table 1 shows sample statistical descriptions by employment status).

First, we utilized some variables used in previous studies ${ }^{7}$. These include individual variables likely to affect employment status choice, such as schooling years, tenure years, health status (very good, good, normal, bad) dummy variables, which are the index of human capital, female (female is a binary variable coded 1 if the respondent is a female and 0 otherwise), and Han race (Han race is a binary variable code 1 if the respondent is Han race, and 0 minority). In addition, it is thought the risk aversion preferences vary with these individual attributes, and the risk aversion preference becomes more likely with increasing age.

Some previous studies indicate that family factors, such as child, marriage status, parent education, and parent occupations, can affect the choice to become a self-employed worker, particularly for female workers. We used a marriage dummy, number of children, parent education (a senior high school and over dummy), and parent occupation (manager dummy) to control the influence of these factors.

As indicated in the liquidity constraint hypothesis, financial factors may affect the choice to become selfemployed, and here, we use living together with parents and household income as the financing constraint index.

It is pointed out that social capital also affects self-employment. It is thought that with higher social capital, there is a greater possibility for settling financial constraint problems and thus a greater chance for success with self-employment. We use two variables_-social relations numbers and frequency of contact to relations-as the index of social capital, using the following questionnaire items: "How many persons do you contact?" and "How frequently do you contact your relations?”

We also consider the influences of some special factors in the Chinese labor market. For example, in urban China, the change from rural registration to urban registration is very difficult except under special conditions, such as workers with higher levels of schooling or with higher skill levels, enlistment in the army, and purchase of a commercial house (investment in housing) in the urban area. It is thought that registration change may influence the choice of employment status, so we add a registration change dummy (a binary variable coded 1 if the worker experienced a registration change and 0 otherwise). In addition, because there are regional disparities

\footnotetext{
${ }^{7}$ For example, Amit et al. (1990), Evans and Leighton (1989), Bruce (1999), Hamilton (2000), Dunn and Holtz-Eakin (2000), Zhang and Pan (2012) pointed out individual attributes (such as gender, human capital, and family background) should affect the choice to become a selfemployed worker. In addition, Evans and Jovanovic (1989), Lentz and Laband (1990), Holtz-Eakin et al. (1994), Dunn and Holtz-Eakin (2000) indicated that financial constraints also affect the entry to the self-employed.
} 
Table 1. Statistical descriptions.

\begin{tabular}{|c|c|c|c|c|c|c|}
\hline & \multicolumn{2}{|c|}{ Employee } & \multicolumn{2}{|c|}{ Employer } & \multicolumn{2}{|c|}{ Own-account } \\
\hline & Mean & S.D. & Mean & S.D. & Mean & S.D. \\
\hline Age & 38 & 11 & 35 & 11 & 38 & 12 \\
\hline Schooling years & 12 & 3 & 11 & 3 & 11 & 3 \\
\hline \multicolumn{7}{|l|}{ Health status } \\
\hline Very good & 0.1839 & 0.3875 & 0.2321 & 0.4241 & 0.1770 & 0.3826 \\
\hline Good & 0.5666 & 0.4956 & 0.6250 & 0.4863 & 0.5694 & 0.4964 \\
\hline Normal & 0.2308 & 0.4214 & 0.1250 & 0.3322 & 0.2344 & 0.4247 \\
\hline Bad & 0.0187 & 0.1354 & 0.0179 & 0.1330 & 0.0191 & 0.1373 \\
\hline Female & 0.5363 & 0.4987 & 0.5357 & 0.5010 & 0.5502 & 0.4987 \\
\hline Minority (han) & 0.9905 & 0.0972 & 0.9911 & 0.0945 & 0.9809 & 0.1373 \\
\hline Married & 0.7654 & 0.4238 & 0.7411 & 0.4400 & 0.7656 & 0.4247 \\
\hline Child & 0.9304 & 0.2544 & 0.9643 & 0.1864 & 0.9426 & 0.2332 \\
\hline Living together with parents & 0.1921 & 0.3940 & 0.2500 & 0.4350 & 0.1962 & 0.3981 \\
\hline Ln household income & 10.8947 & 0.6416 & 11.1407 & 0.5505 & 10.7339 & 0.7303 \\
\hline Parent: Senior high school and over & 0.2152 & 0.4110 & 0.1518 & 0.3604 & 0.1627 & 0.3700 \\
\hline Parent: Manager & 0.0698 & 0.2548 & 0.0714 & 0.2587 & 0.0383 & 0.1923 \\
\hline Hukou change & 0.0597 & 0.2369 & 0.1696 & 0.3770 & 0.1292 & 0.3362 \\
\hline Relations numbers & 38 & 44 & 36 & 32 & 32 & 29 \\
\hline \multicolumn{7}{|l|}{ The frequency of contact to relations } \\
\hline One time weekly & 0.5994 & 0.4901 & 0.5446 & 0.5002 & 0.4737 & 0.5005 \\
\hline One time monthly & 0.3368 & 0.4726 & 0.3839 & 0.4885 & 0.4689 & 0.5002 \\
\hline One time yearly & 0.0638 & 0.2445 & 0.0714 & 0.2587 & 0.0574 & 0.2332 \\
\hline \multicolumn{7}{|l|}{ Regions } \\
\hline East & 0.5361 & 0.4987 & 0.5714 & 0.4971 & 0.3684 & 0.4835 \\
\hline West & 0.1727 & 0.3780 & 0.1607 & 0.3689 & 0.1914 & 0.3943 \\
\hline Central & 0.2912 & 0.4544 & 0.2679 & 0.4448 & 0.4402 & 0.4976 \\
\hline Number of observations & 5,247 & & 112 & & 209 & \\
\hline
\end{tabular}

Source: Calculated using CHIP2007.

in China, it is thought that labor demands vary by region, so we add three regional dummies (West, East, and Central regions).

In order to test the hypothesis, wage ${ }^{8}$ premiums (wage differentials between employment status groups) are calculated - the wage ratio of own-account worker to employee (Woa/Wee) and wage ratio of self-employed employer to employee (Wer/Wee) ${ }^{9}$. As the distribution of this variable is skewed, its natural logarithmic forms are used.

\footnotetext{
${ }^{8}$ Wage survey items in CHIP2007 for urban registration residents comprises the basic wage, bonus, cash subsidy, and no cash subsidy, whereas the wage survey for migrants comprises the basic wage, so the logarithm of the monthly wage based on the basic wage is utilized in the paper.

${ }^{9}$ Wage premiums are calculated based on estimated results of wage functions by employment status groups.
} 
We also distinguish employee wages by private and public sector and perform robust checks to test the hypotheses. Reduced earning function estimation results are utilized to calculate these imputed wages and wage differentials.

This paper focuses on self-employed employers, own-account workers, employees, and the unemployed. Considering that the retirement system is structured within the public sector, in order to diminish the effect of that system on analysis results, the analytic objects are limited to groups between the ages of 16 and 60 . The samples utilized in the following empirical studies comprise 10,806 urban residents and 6,267 migrants.

\section{Descriptive Statistics Results}

\subsection{Distributions of Employment Status in Urban China}

The distributions of employment status of urban registration residents in urban China are shown in Table 2, the divisions are as follows: 1.4 percentage self-employed employers, 2.71 percentage own-account workers, 65.84 percentage employees, and 30.02 percentage the unemployed.

\subsection{Wages, Working Hours and Household Income by Employment Status Groups}

Mean values and standard deviations of wages, working hours, and household income by employment status group are shown in Table 3, Kernel density estimation results are expressed in Figures 1-3.

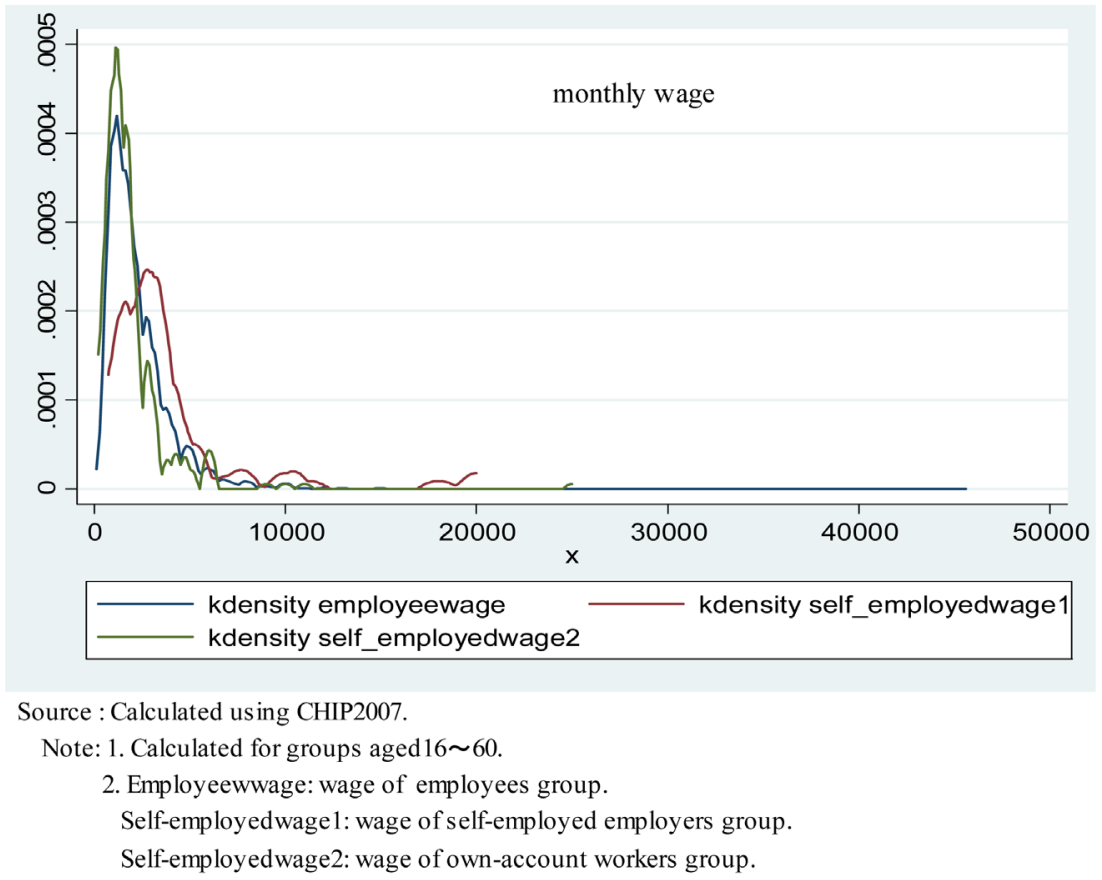

Figure 1. Kernel density estimations of monthly wage by employment status groups.

Table 2. Distributions of employment status in urban China.

\begin{tabular}{|c|c|c|c|c|}
\hline & Total & East & Central & West \\
\hline Self-employed employer & $1.43 \%$ & $1.59 \%$ & $1.38 \%$ & $1.11 \%$ \\
\hline Own-account worker & $2.71 \%$ & $1.99 \%$ & $3.64 \%$ & $3.01 \%$ \\
\hline Employee & $65.84 \%$ & $68.70 \%$ & $63.67 \%$ & $62.43 \%$ \\
\hline The unemployed & $30.02 \%$ & $27.72 \%$ & $31.31 \%$ & $33.45 \%$ \\
\hline Total & $100.00 \%$ & $100.00 \%$ & $100.00 \%$ & $100.00 \%$ \\
\hline Number of observations & 10,806 & 5,224 & 3,325 & 2,257 \\
\hline
\end{tabular}

Source: Calculated using CHIP2007. Note: Calculated for groups aged 16 - 60. 


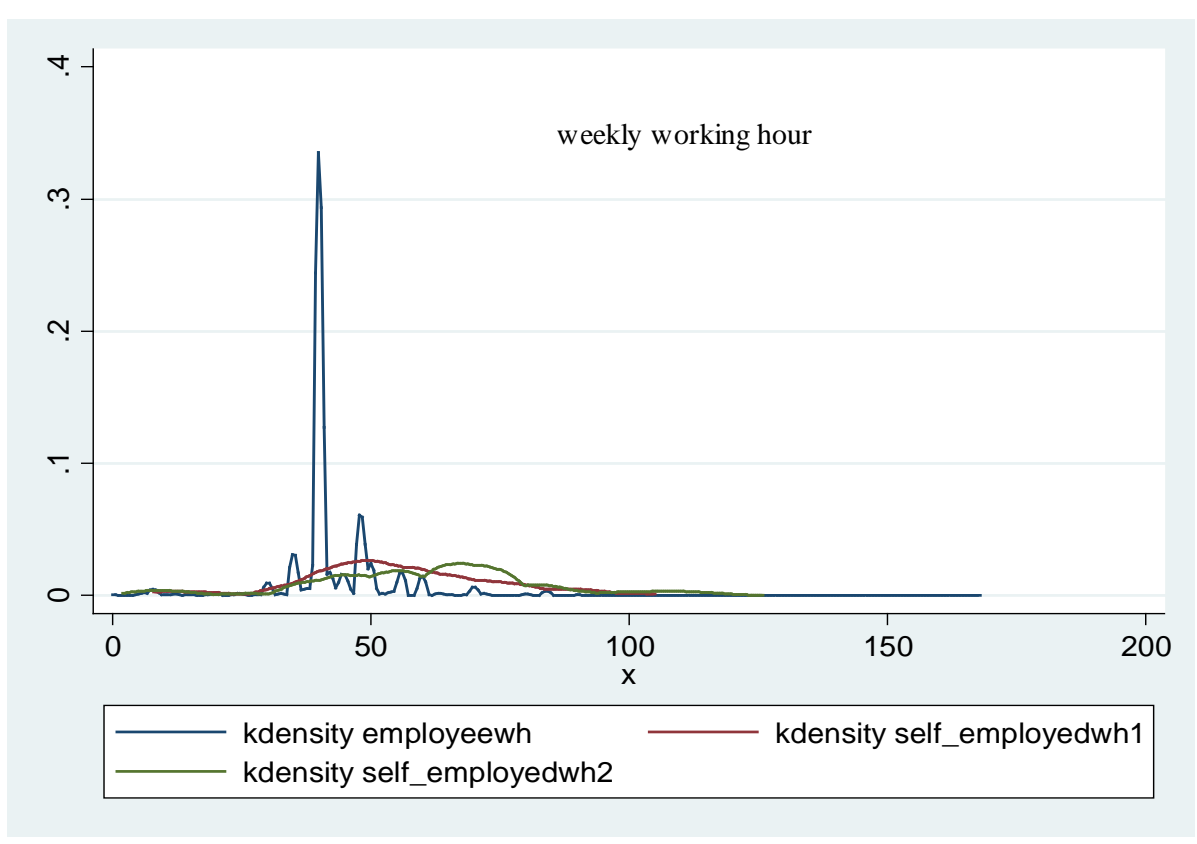

Source : Calculated using CHIP2007.

Note: 1. Calculated for groups aged16 60.

2. Employeewh: working hours of employees group.

Self-employedwh1: working hours of self-employed employers group.

Self-employedwh2: working hours of own-account workers group.

Figure 2. Kernel density estimations of weekly working hours by employment status groups.

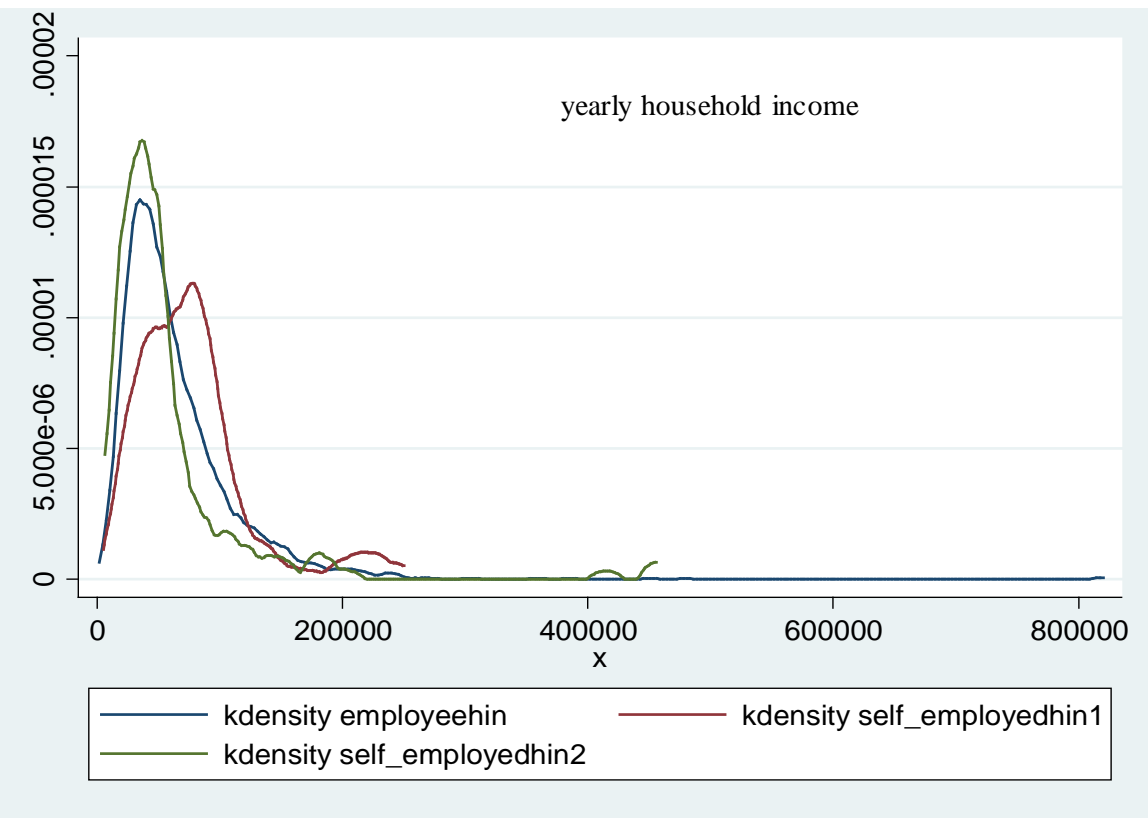

Source : Calculated using CHIP2007.

Note: 1 . Calculated for groups aged $16 \sim 60$.

2. Employeehin: yearly household income of employees group.

Self-employedhin1: yearly hous ehold inocme of self-employed employers group.

Self-employedhin2: yearly household income of own-account workers group.

Figure 3. Kernel density estimations of yearly household income by employment status groups. 
Table 3. Wages, working hours and household income by employment status groups.

\begin{tabular}{cccccccc}
\hline & & Employee & Employer & Own-account & oa/ee & er/ee \\
\hline \multirow{2}{*}{ Monthly earning (Yuan) } & Mean & 2238 & 3802 & 1882 & 0.84 & 1.70 \\
& Std deviation & 1831 & 3802 & 2022 & 1.10 & 2.08 \\
Weekly working hours (hour) & Mean & 42 & 55 & 61 & 1.45 & 1.31 \\
& Std deviation & 10 & 18 & 22 & 2.20 & 1.80 \\
Yearly household income (Yuan) & Mean & 64966 & 76892 & 59158 & 0.91 & 1.18 \\
& Std deviation & 52247 & 46686 & 67007 & 1.28 & 0.89 \\
\hline
\end{tabular}

Source: Calculated using CHIP2007.

Considering average wages for each group, compared with employees group, wages are higher for selfemployed employers group (er/ee 1.70) and lower for own-account workers group (oa/ee 0.84). There are working hour disparities among employment status groups. Concretely, compared with employees group, the working hours are longer for both own-account workers group (oa/ee 1.45) and self-employed employers group (er/ee 1.31). However, the household income differentials by employment status group are smaller.

Kernel density estimation results show that compared with employees and own-account workers groups, wage and household income are higher for self-employed employers group. In addition, compared with employees, most of self-employed workers (either self-employed employers group or own-account workers group) are working in longer time.

Although these tabulated calculations indicate the existence of wage, work hours, and household income differentials by employment status group, it is not clear as to what determines the choice of employment status and which hypothesis explains self-employment. These questions will be answered using the econometric analysis results discussed in the following section.

\section{Econometric Analysis Results}

\subsection{What Determines a Worker's Entry into the Self-Employment Sector?}

Table 4 indicates the estimated results of the determinants of entry into the self-employment sector, except for the wage premium. The main findings are as follows.

First, self-employed employer increases with increase in the household income. This can be explained by the existence of financial constraints for self-employed employers in these two groups. This result provides evidence that in trying to create new jobs or businesses, policies (such as financial support policies for small enterprise) to resolve financial constraint problems are important in a transition economy (and elsewhere).

Second, the Hukou (registration) system influences entry into the self-employment sector. Concretely, the experience of change from the rural registration to the urban registration increases the probability of becoming a self-employed employer or an own-account worker. It is indicated that compared with the local urban registration residents group, urban residents through migration mostly work in the informal sector. This result is consistent with previous studies on Mexican immigrants and self-employment (Waldinger, 1986; Borjas, 1986) ${ }^{10}$.

Third, considering social capital, compared with the workers who contact relations once every week, those who contact relations once every month are more likely to become own-account worker.

Finally, compared with workers in the West and Central regions, the probability of becoming a self-employed worker is lower for those in the East region. This may be because compared with the West and the Central regions, the level of economic development is higher in the East region, so labor demands are also relatively higher in that region.

\subsection{Do Self-Employed Workers Gain More Income than Employees?}

Next, we turn to the hypothesis test results. First, the multivariable regression analysis of wages based on Equations (2.1)-(2.3) is shown in Table 5.

\footnotetext{
${ }^{10}$ Waldinger (1986), Borjas (1986) pointed out that compared with the domestic residents (the U.S. residents), Mexican immigrants are more likely to work in the informal sector and become self-employed workers.
} 
Table 4. The determinants of entry into the self-employment sector.

\begin{tabular}{|c|c|c|c|c|c|c|}
\hline & \multicolumn{2}{|c|}{ Employer } & \multicolumn{2}{|c|}{ Own-Account } & \multicolumn{2}{|c|}{ Unemployed } \\
\hline & coeff. & z-value & coeff. & z-value & coeff. & z-value \\
\hline Age & 0.0265 & 0.35 & -0.0469 & -0.90 & $-0.2395^{* * *}$ & -11.08 \\
\hline Age squared/100 & -0.0881 & -0.92 & 0.0382 & 0.59 & $0.4003^{* * *}$ & 15.44 \\
\hline Schooling years & $-0.1496^{* * * *}$ & -4.65 & $-0.1075^{* * * *}$ & -4.58 & $-0.0228^{* *}$ & -2.51 \\
\hline \multicolumn{7}{|l|}{ Health status (bad) } \\
\hline Very good & -0.2164 & -0.29 & -0.0438 & -0.08 & $-1.1097^{* * *}$ & -6.44 \\
\hline Good & -0.1989 & -0.27 & 0.0749 & 0.14 & $-1.0552^{* * *}$ & -6.79 \\
\hline Normal & -0.8052 & -1.05 & 0.1397 & 0.26 & $-0.7854^{* * *}$ & -4.97 \\
\hline Female & 0.0954 & 0.48 & 0.0901 & 0.62 & $-1.4926^{* * *}$ & -21.97 \\
\hline Minority (han) & -0.2601 & -0.25 & -0.8080 & -1.51 & -0.1477 & -0.46 \\
\hline Married & 0.5539 & 1.43 & $0.4617^{*}$ & 1.63 & -0.0076 & -0.07 \\
\hline Child & $1.0203^{*}$ & 1.90 & 0.1342 & 0.41 & 0.1074 & 0.56 \\
\hline Living together with parents & 0.3225 & 1.43 & 0.0479 & 0.27 & -0.0848 & -1.03 \\
\hline Household income & $0.8297^{* * *}$ & 5.24 & -0.0702 & -0.56 & $-0.5672^{* * *}$ & -10.36 \\
\hline Parent: Senior high school and over & -0.3758 & -1.37 & -0.1696 & -0.86 & $-0.2221^{* * *}$ & -2.59 \\
\hline Parent: Manager & 0.1794 & 0.47 & $-0.6076^{*}$ & -1.64 & -0.1116 & -0.86 \\
\hline Hukou change methods & $0.7962^{* * *}$ & 2.91 & $0.7764^{* * *}$ & 3.47 & 0.4577 & 3.67 \\
\hline Relations & -0.0025 & -1.03 & -0.0022 & -1.06 & $-0.0042^{* * *}$ & -4.14 \\
\hline \multicolumn{7}{|l|}{$\begin{array}{l}\text { The frequency of contact to relations } \\
\text { (one time weekly) }\end{array}$} \\
\hline One time monthly & 0.2486 & 1.22 & $0.5705^{* * *}$ & 3.88 & $0.1091^{*}$ & 1.68 \\
\hline One time yearly & 0.2911 & 0.75 & 0.1711 & 0.55 & -0.0834 & -0.63 \\
\hline \multicolumn{7}{|l|}{ Region (West + Central regions) } \\
\hline East region & -0.2103 & -1.00 & $-0.6498^{* * *}$ & -4.07 & $-0.1693^{* *}$ & -2.55 \\
\hline Constant & $-11.8432^{* * *}$ & -4.86 & 0.2498 & 0.14 & $9.5793^{* * *}$ & 11.89 \\
\hline Number of observations & & & 7,744 & & & \\
\hline Log likelihood & & & -4718.812 & & & \\
\hline Pseudo $\mathrm{R}^{2}$ & & & 0.2180 & & & \\
\hline Chi-squared & & & 2630.71 & & & \\
\hline
\end{tabular}

Source: Calculated using CHIP2007. Note: 1$)^{*},{ }^{* *},{ }^{* * *}$ : statistical significant in 10\%, 5\%, $1 \%$ level. 2 ) Reference category = employee group.

Table 5. The results of wage functions by employment status groups.

\begin{tabular}{|c|c|c|c|c|c|c|c|c|}
\hline & \multicolumn{2}{|c|}{ Total samples } & \multicolumn{2}{|c|}{ Employee } & \multicolumn{2}{|c|}{ Employer } & \multicolumn{2}{|c|}{ Own-account } \\
\hline & coeff. & t-value & coeff. & t-value & coeff. & t-value & coeff. & t-value \\
\hline \multicolumn{9}{|c|}{ Employment status (employee) } \\
\hline Self-employed employer & $0.3034^{* * *}$ & 5.49 & & & & & & \\
\hline Own-account worker & $-0.2695^{* * *}$ & -5.99 & & & & & & \\
\hline
\end{tabular}




\begin{tabular}{|c|c|c|c|c|c|c|c|c|}
\hline \multicolumn{9}{|l|}{ Continued } \\
\hline Age & $-0.0983^{* * *}$ & -13.42 & $-0.0603^{* * *}$ & -8.10 & 0.0461 & 0.57 & $0.0959^{*}$ & 1.96 \\
\hline Age squared/100 & $0.1619^{* * *}$ & 15.53 & $0.0921^{* * *}$ & 8.99 & -0.0965 & -0.87 & $-0.1787^{* * *}$ & -2.90 \\
\hline Tenure years & $0.0295^{* * *}$ & 10.04 & $0.0353^{* * *}$ & 11.48 & $-0.0875^{* *}$ & -2.52 & 0.0180 & 0.65 \\
\hline Tenure years squared/100 & $-0.0485^{* * *}$ & -5.69 & $-0.0651^{* * *}$ & -7.33 & $0.3086^{* *}$ & 2.49 & -0.0020 & -0.02 \\
\hline Schooling years & $0.0188^{* * *}$ & 5.43 & $0.0188^{* * *}$ & 6.02 & $0.0619^{*}$ & 1.64 & 0.0378 & 1.51 \\
\hline Learning achievement & $0.0551^{* * *}$ & 2.99 & $0.0974^{* * *}$ & 5.04 & 0.2537 & 1.55 & $-0.2908^{* *}$ & -2.06 \\
\hline \multicolumn{9}{|l|}{ Health status (bad) } \\
\hline Very good & $-0.4178^{* * *}$ & -5.91 & $-0.2505^{* * *}$ & -3.42 & $-1.0563^{*}$ & -1.85 & -0.4448 & -0.82 \\
\hline Good & $-0.3230^{* * *}$ & -4.70 & $-0.1997^{* * *}$ & -2.81 & -0.2319 & -0.41 & -0.3076 & -0.59 \\
\hline Normal & $-0.2012^{* * *}$ & -2.94 & $-0.1715^{* *}$ & -2.42 & -0.6567 & -1.13 & -0.8355 & -1.58 \\
\hline Female & $-0.5782^{* * *}$ & -19.03 & $-0.2622^{* * *}$ & -10.02 & 0.0020 & 0.01 & 0.1475 & 1.07 \\
\hline Minority (han) & -0.0965 & -1.12 & -0.0376 & -0.42 & -0.7504 & -0.91 & -0.4477 & -0.91 \\
\hline Married & $0.0556^{*}$ & 1.73 & $0.1027^{* * *}$ & 3.18 & $0.8314^{*}$ & 2.51 & $0.6953^{* * *}$ & 2.59 \\
\hline Training & 0.0281 & 1.60 & $0.0545^{* * *}$ & 2.96 & $-0.3336^{*}$ & -1.89 & $-0.2626^{*}$ & -1.88 \\
\hline \multicolumn{9}{|l|}{ Industrials (no-manufacture) } \\
\hline Manufacture & $-0.1386^{* * *}$ & -7.55 & $-0.1708^{* * *}$ & -8.85 & -0.2173 & -1.35 & -0.1479 & -1.09 \\
\hline \multicolumn{9}{|c|}{ Region (West + Central regions) } \\
\hline East region & $0.2278^{* * *}$ & 10.60 & $0.3531^{* * *}$ & 18.10 & $0.6384^{* * *}$ & 3.05 & 0.1600 & 1.10 \\
\hline Lambda (employees) & $9.4229^{* * *}$ & 14.99 & $-3.7639^{* * *}$ & -15.15 & - & - & - & - \\
\hline Lambda (employers) & $-18.1061^{* * *}$ & -22.76 & - & - & -0.4268 & -0.14 & - & - \\
\hline Lambda (own-account) & $-2.3523^{* *}$ & -2.26 & - & - & - & - & 6.1358 & 1.14 \\
\hline Constant & $12.4516^{* * *}$ & 13.56 & $4.3043^{* * *}$ & 17.19 & 2.6810 & 0.86 & -3.7273 & -0.93 \\
\hline Number of observations & 5,389 & & 5,054 & & 110 & & 203 & \\
\hline adj R-squared & 0.3232 & & 0.2540 & & 0.3323 & & 0.2292 & \\
\hline
\end{tabular}

Source: Calculated using CHIP2007. Note: ${ }^{*},{ }^{* *},{ }^{* * *}$ : statistical significant in 10\%, 5\%, $1 \%$ level.

The results using subsamples show a standard shape of the wage function for employees, particularly in terms of human capital variables and gender, whereas the effects of these factors on the wages of self-employed employers and own-account workers are small. In addition, estimated results show the existence of wage differentials between employment status groups. For example, compared with the employee and holding other factors (e.g., human capital) constant, wages are higher for the self-employed employer, whereas wages are lower for the own-account self-employed worker than that for the employee. Holding other factors constant, a worker can gain more economic benefits by becoming a self-employed employer but gains less by becoming an own-account employer. Compared with the employee, the economic benefit for the self-employed employer is better, but it is worse for the own-account worker. Based on these estimated results, the disguised unemployment and business creation hypotheses are not clearly supported.

\subsection{Hypothesis Test: Business Start-Up or Disguised Unemployment?}

In order to directly test these hypotheses using the imputed wages calculated based upon the results shown in Table 5, the reduced multinomial logit analysis is estimated. These estimated results are represented in Table 6 . 
Table 6. The results of hypothesis tests.

\begin{tabular}{|c|c|c|c|c|}
\hline & \multicolumn{2}{|c|}{ Employer } & \multicolumn{2}{|c|}{ Own-account } \\
\hline & coeff. & z-value & coeff. & z-value \\
\hline \multicolumn{5}{|l|}{ Panel A: Total } \\
\hline Log (Woa/Wee) & 0.0625 & 0.16 & 0.4344 & 1.50 \\
\hline Log (Wer/Wee) & -0.3606 & -1.36 & -0.0836 & -0.45 \\
\hline \multicolumn{5}{|l|}{ Panel B: Wage levels by sectors } \\
\hline Log (Woa/Weepri) & $-0.5881^{*}$ & -1.71 & -0.2580 & -1.02 \\
\hline Log (Wer/Weepri) & $-0.4643^{* *}$ & -2.14 & 0.0256 & 0.17 \\
\hline Log (Woa/Weepub) & -0.2763 & -0.68 & 0.3085 & 1.03 \\
\hline Log (Wer/Weepub) & $-0.4242^{*}$ & -1.96 & 0.1013 & 0.67 \\
\hline \multicolumn{5}{|l|}{ Panel C: Entry periods } \\
\hline \multicolumn{5}{|l|}{ SOE reform period } \\
\hline Log (Woa/Wee) & $1.7760^{* * *}$ & 2.54 & $1.0779^{* *}$ & 2.10 \\
\hline Log (Wer/Wee) & $-1.1126^{* *}$ & -2.17 & $-1.0640^{* * *}$ & -2.92 \\
\hline \multicolumn{5}{|l|}{ Recent period } \\
\hline Log (Woa/Wee) & 0.6170 & 0.86 & 0.6736 & 1.39 \\
\hline Log (Wer/Wee) & $-1.5110^{* *}$ & -2.25 & 0.3453 & 0.75 \\
\hline \multicolumn{5}{|l|}{ Panel D: Age groups } \\
\hline Log (Woa/Wee) & 0.0043 & 0.01 & 0.3111 & 1.07 \\
\hline Log (Wer/Wee) & -0.3898 & -1.38 & 0.1610 & 0.80 \\
\hline Log (Woa/Wee) ${ }^{*}$ aged 50 and over & 0.9859 & 1.59 & $0.7143^{*}$ & 1.88 \\
\hline Log (Wer/Wee) ${ }^{*}$ aged 50 and over & 0.2867 & 0.46 & $-1.2099^{* * *}$ & -2.83 \\
\hline \multicolumn{5}{|l|}{ Panel E: Regional groups } \\
\hline \multicolumn{5}{|l|}{ East region } \\
\hline Log (Woa/Wee) & -0.2658 & -0.51 & 0.4150 & 0.84 \\
\hline Log (Wer/Wee) & $-0.8592^{* *}$ & -2.26 & 0.1126 & 0.38 \\
\hline \multicolumn{5}{|l|}{ Central/West region } \\
\hline Log (Woa/Wee) & 0.5484 & 0.91 & 0.4239 & 1.15 \\
\hline Log (Wer/Wee) & 0.1454 & 0.38 & -0.1806 & -0.76 \\
\hline
\end{tabular}

Source: Calculated using CHIP2007. Note: 1$)^{*},{ }^{* *},{ }^{* * *}$ : statistical significant in $10 \%, 5 \%, 1 \%$ level. 2 ) The specification of strauctural MNL is similar to that shown in Table 4, but dependent variable has only three categories (omitting the unemployed group) and the imputed wage differentials $\log ($ Woa/Wee $)$ and $\log ($ Wer/Wee $)$ are added to the regressors. All other independent variables shown in Table 4 are also included here, but not be shown.

First (Panel A), the results show that the wage premium (logWoa/Wee, logWer/Wee) does not statistically affect the probability of employment status. Based on the individual utility maximum rule (e.g., to gain the highest income), workers possibly chooses to become a self-employed employer or an own-account worker when their associated wage levels are higher than those for employees. There is no significant positive relation between the wage premium and the probability of being self-employed, indicating that the choice to enter the self-employment sector (as either self-employed employers or own-account workers) does not result from perceived economic gains and benefits. These results support the disguised unemployment hypothesis, whereas the business creation hypothesis is rejected. 
Second, as shown in Panel B, considering the labor market in urban China is segmented by the public and private sectors ${ }^{11}$, and the wage level in the informal sector is close to that in the private sector, we analyze the estimated results of the effects of wage premiums between the private sector and other sectors in the following discussion. The influences of wage premiums (logWer/Weepri) on the probability of becoming a self-employed employer are negatively significant $(-0.4643)$. These results are consistent with the above, and the disguised unemployment hypothesis is supported, whereas the business creation hypothesis is rejected. In addition, the influence of the wage premium (logWoa/Weepri) on the probability of becoming an own-account worker is insignificant, so the business creation hypothesis is rejected in these two groups again.

Third, as shown in Panel C, as described above, in the 1990s, the Chinese government enforced ownership reform in SOEs. As a result, a section of workers were displaced, and some of them entered into informal sectors. In contrast, some workers voluntarily left SOEs to become self-employed employers. If the effects of those who left voluntarily is greater than those who were displaced, the wage premium should positively affect the choice to become a self-employed employer or an own-account worker. We considered the subsample of those with more than 10 years tenure as the group who entered the self-employed sector before 1997 (named the "SOE reform period") and the subsample with less than 5 years tenure as the group who entered into the self-employed sector after 2003 (named the "recent period"). The influence of wage premiums (logWer/Wee) on the probability of becoming a self-employed employer is negatively significant in both the SOE reform period and the recent period (the SOE reform period -1.1126 , and the recent period -1.5110). These results indicate that the choice to become self-employed does not result from the perceived economic gains and benefits; it is more likely an involuntarily choice or behavior. In other words, a worker is pushed into the self-employed sector to make a living. Based on these results, in the self-employed worker group, the business creation hypothesis is also rejected in both periods. However, the influence of wage premiums (logWoa/Wee) on the probability of becoming an own-account worker is positively significant in the SOE reform period (1.0779). This indicates that the choice to become an own-account worker results from perceived economic gains and benefits. Therefore, this is perhaps a voluntarily behavior among the own-account workers group, the business creation hypothesis is supported in the SOE reform period.

Fourth, as shown in Panel D, as indicated in previous studies, risk aversion preferences become stronger with increasing age. The choice of becoming a worker in the self-employment sector is different by age groups. Two subsamples were utilized to test the hypothesis again - the age 50 and over group and the under age 50 group. In the group aged 50 and over, the influences of wage premiums (logWoa/Wee) on the probability of becoming an own-account worker is positively significant $(0.7143)$ at the $10 \%$ level. Compared with the younger workers, middle-aged and elderly workers are more likely to become own-account workers based on perceived economic gains and benefits. The business creation hypothesis is rejected in the younger group while it is more likely supported in the middle-aged and elderly groups.

Fifth, as shown in Panel E, the influence of wage premiums (logWer/Wee) on the probability of becoming a self-employed employer is negatively significant in the East region $(-0.8592)$, while the influences of wage premiums on the probability of becoming an own-account workers are insignificant in both the Central/West regions. The business creation hypothesis is rejected again in each region.

\section{Conclusions}

This paper provides evidence on the determinants of self-employment for urban registration residents and migrants in urban China. Using CHIP2007, the employment status is divided into four categories: self-employed employers, own-account workers, employees, and the unemployed. Several major conclusions emerge.

First, compared with the employee, holding other factors (e.g., human capital) constant, the wage premium associated with the self-employed employer is higher, while the wage premium associated with own-account workers is lower.

Second, the effects of the sample-selection-bias-corrected wage premium for self-employed employers are insignificant. The business creation hypothesis is rejected, while the disguised unemployment hypothesis is supported, showing that the self-employed workers possibly works in sectors with lower economic benefits.

Third, considering the influence of all the factors: the wage level categories (wage levels in the public and

\footnotetext{
${ }^{11}$ For empirical studies on labor market segmentation by public and private sector in urban China, please see Dong and Bowels (2002), Xing Chunbin (2006), Yin Zhichao, \& Gan Li (2009), Lu Zhengfei, Wang Xiongyuan, \& Zhang Peng (2012), Chen et al. (2005), Zhang Juwei, \& Xue Xinxin (2008), Demurger et al. (2012), Zhang Yibo (2012), and Ma (2009, 2014, 2015, 2016).
} 
private sectors), the entry period categories (the SOE reform period and the recent period), the age categories (aged 50 and over, and aged below 50), and the regional categories (the East, the Central, and the West regions), robust checks were conducted. In the own-account workers group, the business creation hypothesis is nearly rejected again; in fact, it is only supported for workers who entered the self-employment sector in the SOE reform period (entered early into the self-employment sector group), and workers aged over 50.

These estimated results revealed that compared with employees, self-employed employers and own-account workers do not gain more, and there seemingly are no better choices in urban China. The one of reasons is that an employer has to face business risks and financial constraints. If the self-employed employer (e.g., the owner of a small private firm) cannot settle the financial constraint problem through the formal financial market (e.g., by getting a loan from a government bank), business continuity will become difficult. Financial constraint problems already exist in China. It is known that the public banks do not like to lend to small private firms, so most small firms gain financial support through informal financial markets (e.g. inter-household risk sharing and illegal loans). The estimated results in this paper showed that the effect of household income on the selfemployed employer group is greater than that for the other groups. In order to promote more new business for greater economic growth in the future, the Chinese government should establish and implement financial support policies for small firms.

Finally, although we conducted an empirical study to reveal the determinants of self-employment and used the hypothesis tests discussed in this paper, there are two points worthy of attention. First, because we utilized one period of cross-sectional data, there might be heterogeneity and endogeneity problems, and a study using panel data should be conducted in the future. Second, this paper is a static analysis for self-employment. It is thought that empirical studies on dynamic changes in self-employment (the transition into and exit from selfemployment) are also important issues (Le, 1999) ${ }^{12}$, so dynamic analysis should be taken in the future studies.

\section{Acknowledgements}

I would like to thank professor Emiiko Usui (Hitotsubashi University), professor Katsuji Nakagane (Tokyo University), professor Kai Kajitani (Kobe University), for their helpful comments in 2014 annual meeting of Japan Association for Asian Studies (JAAS), the 2013 annual meeting of Japanese Economic Association (JEA), the 2013 annual meeting of Japanese Association for Chinese Economics and Management Studies (JACEMS).

\section{Funding}

This research was supported by JSPS KAKENHI Grand Number JP16K03611, and Joint Usage and Research Center Project, Institute of Economic Research, Hitotsubashi University.

\section{Note}

Data used for the study was provided by the Income Inequality Research Center, Beijing Normal University.

\section{References}

Amit, R., Glosten, L., \& Muller, E. (1990). Entrepreneurial Ability, Venture Investments, and Risk Sharing. Management Science, 36, 1232-1245. http://www.jstor.org/stable/2632662 http://dx.doi.org/10.1287/mnsc.36.10.1233

Bates, T. (1990). Entrepreneur Human Capital Inputs and Small Business Longevity. The Review of Economics and Statistics, 72, 551-559. http://dx.doi.org/10.2307/2109594

Blanchflower, D. G., \& Meyer, B. (1992). A Longitudinal Analysis of Young Entrepreneurs in Australia and the United States. In R. G. Gregory, \& R. Karmel (Eds.), Youth in the Eighties, Papers from the Australian Longitudinal Survey Research Project. Canberra: DEET and Centre for Economic Policy Research, Australian National University.

Blau, D. M. (1987). A Time-Series Analysis of Self-Employment in the United States. Journal of Political Economy, 95, 445-467. http://www.jstor.org/stable/1831972 http://dx.doi.org/10.1086/261466

Borjas, J. (1986). The Self-Employment Experience of Immigrants. The Journal of Human Resources, 21, 485-506. http://dx.doi.org/10.2307/145764

Bruce, D. (1999). Do Husband Matter? Married Women Entering Self-Employment. Small Business Economics, 13, 317329. http://dx.doi.org/10.1023/A:1008179214572

${ }^{12}$ For longitudinal analysis using panel data, please see Blau (1987), Evans and Jovanonic (1989), Blanchflower and Meyer (1992), Xie E

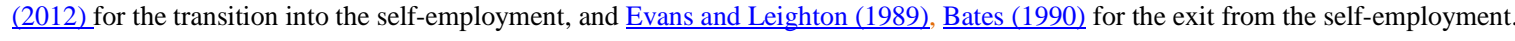


Chen, G., Demurger, S. \& Fournier, M. (2005). Earnings Differentials and Ownership Structure in Chinese Enterprises. Economic Development and Cultural Change, 53, 933-958.

http://www.jstor.org/action/showPublication?journalCode=econdevecultchan

http://dx.doi.org/10.1086/429845

De Soto, H. (1989). The Other Path: The Invisible Revolution in the Third World. London: I.B. Tauris \& Co.

Demurger, S., Li, S., \& Yang, J. (2012). Earning Differentials between the Public and Private Sectors in China: Exploring Changes for Urban Local Residents in the 2002s. China Economic Review, 23, 138-153. http://dx.doi.org/10.1016/j.chieco.2011.08.007

Dimova, R., \& Gang, I. N. (2007). Self-Selection and Wages during Volatile Transition. Journal of Comparative Economics, 35, 612-629. http://dx.doi.org/10.1016/j.jce.2007.05.003

Dong, X., \& Bowles, P. (2002). Segmentation and Discrimination in China’s Emerging Industrial Labor Market. China Economic Review, 13, 170-196. http://dx.doi.org/10.1016/S1043-951X(02)00057-3

Dunn, T. A., \& Holtz-Eakin, D. (2000). Financial Capital, Human Capital, and Transition to Self-Employment: Evidence from Intergenerational Links. Journal of Labor Economics, 18, 282-305. http://dx.doi.org/10.1086/209959

Earle, J. S., \& Sakova, Z. (2000). Business Start-Ups or Disguised Unemployment? Evidence on the Character of SelfEmployment from Transition Economics. Labor Economics, 7, 575-601. http://dx.doi.org/10.1016/S0927-5371(00)00014-2

Evans, D. S., \& Jovanovic, B. (1989). An Estimated Model of Entrepreneurial Choice under Liquidity Constraints. Journal of Political Economy, 97, 808-827. http://www.jstor.org/stable/1832192 http://dx.doi.org/10.1086/261629

Evans, D. S., \& Leighton, L. (1989). Some Empirical Aspects of Entrepreneurship. American Economic Review, 79, $519-535$. http://www.jstor.org/stable/1806861

Hamilton, B. H. (2000). Does Entrepreneurship Pay? The Journal of Political Economy, 108, 604-631. http://dx.doi.org/10.1086/262131

Hanley, E. (2000). Self-Employment in Post-Communist Eastern Europe: A Refuge from Poverty or Road to Riches. Communist and Post-Communist Studies, 33, 379-402. http://dx.doi.org/10.1016/S0967-067X(00)00012-X

Harris, J. R., \& Todarro, M. P. (1970). Migration, Unemployment and Development: A Two Sector Analysis. The American Economic Review, 60, 126-142. http://www.jstor.org/stable/1807860

Holtz-Eakin, D., Joulfaian, D., \& Rosen, H. S. (1994). Sticking It out: Entrepreneurial Survival and Liquidity Constraints. Journal of Political Economy, 102, 53-75. http://www.jstor.org/stable/2138793 http://dx.doi.org/10.1086/261921

International Labor Organization (1972). Employment, Incomes and Equality: A Strategy for Increasing Productive Employment in Kenya. Geneva: ILO.

Knight, J., \& Song, L. (1999). The Rural-Urban Divide: Economic Disparities and Interactions in China. Oxford: Oxford University Press. http://dx.doi.org/10.1093/acprof:oso/9780198293309.001.0001

Le, A. T. (1999). Empirical Studies of Self-Employment. Journal of Economic Surveys, 13, 381-461. http://dx.doi.org/10.1111/1467-6419.00088

Lentz, B. F., \& Laband, D. N. (1990). Entrepreneurial Success and Occupational Inheritance among Proprietors. Canadian Journal of Economics, 23, 563-579. http://dx.doi.org/10.2307/135648

Lewis, W. A. (1954). Economic Development with Unlimited Supplies of Labor. Manchester School, 22, 139-191. http://dx.doi.org/10.1111/j.1467-9957.1954.tb00021.x

Lu Zhengfei, Wang Xiongyuan, \& Zhang Peng 陆正飞, 王雄元, 张鹏 (2012). Do Chinese State-Owned Enterprises Pay High Wage? 国有企业支付了更高的职工工资吗? Economic Research Journal, 3, 28-39.

Ma, X. (2009). The Enterprise Ownership Reforms and the Change of Wage Structure in China: Comparison of Gender Wage Profiles Differentials by Ownership. Journal of Chinese Economic Studies, 6, 48-64. (In Japanese)

Ma, X. (2014). Wage Policy: Economy Transition and Wage Differentials by Sectors. In N. Katsuji (Ed.), How Did Chinese Economy Change? Evaluation on Economy Systems and Policies after the Economy Reform Period. Tokyo: Kokusei Sioyin Co., Ltd. (In Japanese)

Ma, X. (2015). Economic Transition and Wage Differentials between Public and Private Sectors in Urban China. China-USA Business Review, 14, 477-494.

Ma, X. (2016). Changes of Wage Structures in Chinese Public and Private Sectors: 1995-2007. Management Studies, 4, 243255.

Maddala, G. S. (1983). Limited-Dependent and Qualitative Variables in Econometrics. New York: Cambridge University Press. http://dx.doi.org/10.1017/CBO9780511810176 
Schumpeter, J. A. (1934). Capitalism, Socialism and Democracy. London: G. Allen \& Unwin.

Todarro, M. P. (1969). A Model of Labor Migration and Urban Unemployment in Less Developed Countries. The American Economic Review, 59, 138-148. http://www.jstor.org/stable/1811100

Waldinger, R. (1986). Immigrant Enterprise, a Critique and Reformulation. Theory and Society, 15, 249-285. http://dx.doi.org/10.1007/BF00156934

Wu, X. (2006). Communist Cadres and Market Opportunities: Entry into Self-Employment in China, 1978-1996. Social Forces, 85, 389-411. http://dx.doi.org/10.1353/sof.2006.0149

Xie E 解严 (2012). Transitions to Non-Farm Self-Employment in China 中国非农自雇活动的转换进入分析. Economic Research Journal, 2, 54-66.

Xing Chunbin 邢春涁 (2006). Wage Determination and Returns to Education in Different Ownerships of China, Evidence from Quantile Regressions 中国不同所有制部门的工资决定与教育回报: 分位回归的证据. World Economic Papers, 1, 1-26.

Yamada, G. (1996). Urban Informal Employment and Self-Employment in Developing Countries: Theory and Evidence. Economic Development and Culture Change, 44, 289-314. http://www.jstor.org/stable/1154404 http://dx.doi.org/10.1086/452214

Yin Zhichao, \& Gan Li 尹志超, 甘犁 (2009). An Empirical Study on Wage Differentials between Public and Nonpublic Sector in China 公共部门和非公共部门工资差异的实证研究. Economic Research Journal, 4, 129-140.

Yueh, L. (2009a). Self-Employment in Urban China: Networking in a Transition Economy. China Economic Review, 20, 471-484. http://dx.doi.org/10.1016/j.chieco.2009.01.002

Yueh, L. (2009b). China’s Entrepreneurs. World Development, 37, 778-786. http://dx.doi.org/10.1016/j.worlddev.2008.07.010

Zhang Juwei, \& Xue Xinxin 张车伟, 薛欣欣 (2008). State and Non-State Sector Wage Differentials and Human Capital Contribution 国有部门和非国有部门工资差异与人力资本贡献. Economic Research Journal, 4, 15-25.

Zhang Yibo 张义博 (2012). The Change of Income Differentials between Public and Nonpublic Sector in China 公共部门 与非公共部门收入差异的变迁. Economic Research Journal, 4, 77-88.

Zhang, J., \& Zhao, Z. (2015). Social-Family Network and Self-Employment: Evidence from Temporary Rural-Urban Migrants in China. IZA Journal of Labor \& Development, 4, 1-21. http://dx.doi.org/10.1186/s40175-015-0026-6

Zhang, Q. F., \& Pan, Z. (2012). Women's Entry into Self-Employment in Urban China: The Role of Family in Creating Gendered Mobility Patterns. World Development, 40, 1201-1212. http://dx.doi.org/10.1016/j.worlddev.2011.11.004

\section{Submit or recommend next manuscript to SCIRP and we will provide best service for you:}

Accepting pre-submission inquiries through Email, Facebook, LinkedIn, Twitter, etc. A wide selection of journals (inclusive of 9 subjects, more than 200 journals)

Providing 24-hour high-quality service

User-friendly online submission system

Fair and swift peer-review system

Efficient typesetting and proofreading procedure

Display of the result of downloads and visits, as well as the number of cited articles

Maximum dissemination of your research work

Submit your manuscript at: http://papersubmission.scirp.org/ 